\title{
Relentless Spirit of Dr T. S. Kanaka
}

\author{
Medha A. Vyas ${ }^{1}$ \\ ${ }^{1}$ Department of Neurosurgery, Sir Gangaram Hospital, New Delhi, \\ India
}

Indian J Neurosurg:2020;9:236

Dr Thanjavur Santhanakrishna Kanaka was not only a fierce and spirited lady but also an extremely skilled neurosurgeon. She fought all the odds and contemporary beliefs about women to become the first female neurosurgeon of India and Asia. This short communication will prove to be a snapshot of the life of the legendary Dr. T.S. Kanaka.

Dr Thanjavur Santhana Krishna Kanaka, born on March 31, 1932 was India's first female neurosurgeon. She was Asia's first and the world's third female neurosurgeon after Dr. Diana Beck and Dr. Aysima Altinok. She completed her MBBS in 1954. During her MS, she had to struggle for an opportunity to scrub and be a part of the surgical team. She received her MS General Surgery degree at the age of 31 in 1963, when it was extremely difficult for a woman to become a surgeon. Her relentless spirit helped her bag a degree in neurosurgery at 36, a PhD at 40, and a Diploma in Higher Education at the age of 51 . She was part of on one of three teams from across the world which performed stereotactic procedures. In India, she was the first neurosurgeon to

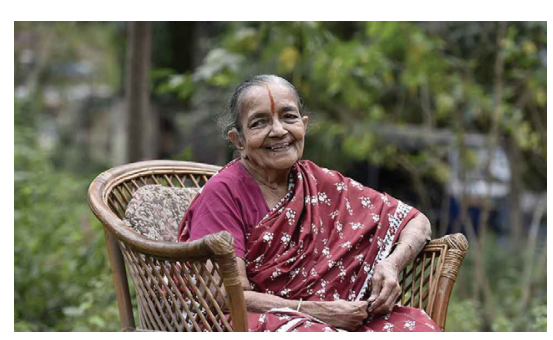

perform chronic electrode implants and deep brain stimulation. For most of her career, she was stationed at Madras Medical College, Tamil Nadu, India. She retired in 1990. In 1996, she became the Honorary President of the Asian Women's Neurosurgical Association and acknowledged as Asia's first female neurosurgeon. After her retirement, she offered free healthcare services at Sri Santhanakrishna Padmavathi Health Care and Research Foundation in Chennai, India. She died on November 14, 2018, at the age of 86 . She paved the way through a male-dominated field and dedicated her life to helping people. Truly, an incredible woman who rose from humble beginnings to become an admirable woman, who fearlessly and relentlessly pushed against patriarchy and continued to follow her dream.

\section{Funding \\ None.}

\section{Conflict of Interest}

None declared.

\section{Address for correspondence}

Dr. Medha A Vyas, DNB Neurosurgery,

MBBS, 1242A, Second Floor,

Sir Gangaram Hospital Old Building,

New Delhi-110060, India

(e-mail: medhavyas4@gmail.com).
DOI https://doi.org/

$10.1055 / \mathrm{s}-0040-1716935$

ISSN 2277-954X. (c) 2020. Neurological Surgeons' Society of India.

This is an open access article published by Thieme under the terms of the Creative Commons Attribution-NonDerivative-NonCommercial-License, permitting copying and reproduction so long as the original work is given appropriate credit. Contents may not be used for commercial purposes, or adapted, remixed, transformed or built upon. (https://creativecommons.org/licenses/by-nc-nd/4.0/)

Thieme Medical and Scientific Publishers Pvt. Ltd., A-12, 2nd Floor, Sector 2, Noida-201301 UP, India 